\title{
Common Cellular Events Implicated in the Regulation of Cold Stress Tolerance and Soft Rot Resistance Induced by Metabolites of Pseudomonas Aeruginosa in Phalaenopsis Orchids
}

\author{
Huey-wen Chuang*, Tony-Seung Tseng, Hsin-Yi Hsieh, Tzu-Chuan Kao, Guan-Hung Chen \\ Department of BioAgricultural Sciences, National Chiayi University, Chiayi, Taiwan \\ E-mail: hwchuang@mail.ncyu.edu.tw
}

Received: 25 November 2020; Revised: 29 December 2020; Accepted: 31 December 2020

\begin{abstract}
Microbial metabolites induce diverse plant physiological responses. In this study, Pseudomonas aeruginosa strain Y1 was shown to produce metabolites exhibiting a high capacity for metal chelation and moderate reducing power activity. In Phalaenopsis orchids, treatments with Y1 metabolites (Y1M) increased the contents of carbohydrates and lignin and the activity of antioxidant enzymes and phenylalanine ammonia lyase (PAL). Y1M treatments increased the tolerance to cold stress $\left(10^{\circ} \mathrm{C}\right)$ by reducing malondialdehyde (MDA) accumulation and electrolyte leakage in a $10^{\circ} \mathrm{C}$ growth environment and enhanced disease resistance against bacterial soft rot caused by Erwinia chrysanthemi. Protein analyses indicated that, in response to Y1M treatment, the protein levels of antioxidant enzymes, such as catalase (CAT) and ascorbate peroxidase (APX); pathogenesis-related (PR) proteins, such as PR-2 and PR-3; and lipoxygenase 1 (LOX1) were increased in Phalaenopsis orchids. Transcriptome analyses indicated that Y1M increased transcription associated with the iron-deficient response mediated by miRNA, the regulation of reactive oxygen species (ROS) homeostasis, and Jasmonic acid (JA) biosynthesis/perception. Gene groups associated with the induced defense response, including cellular events of pattern-triggered immunity (PTI), hypersensitive response (HR), synthesis of the PR protein, and callose formation, were also increased by the Y1M treatments. Transcription factors involved in regulating the cold stress response, such as C-repeat binding factor 1 (CBF1), and cell strengthening, such as MYB26, also had increased expression. In summary, Y1M can activate cellular pathways implicated in regulating stress tolerance shared by cold stress and bacterial invasion.
\end{abstract}

Keywords: plant growth promoting rhizobacteria (PGPR), iron deficient response, cell wall strengthening, bacterial soft rot, low temperature tolerance

\section{Introduction}

As sessile organisms, plants are concurrently exposed to both abiotic and biotic stresses. During evolution, plants have developed effective mechanisms to cope with various adverse environments. A body of research has revealed significant cross-talk in the regulatory network implicated in the adaptive process toward biotic and abiotic stress conditions. Among them, fine tuning of ROS homeostasis regulates plant growth and acclimation physiology in adverse environments. Various abiotic stresses impact metabolism, resulting in the accumulation of ROS [1]. ROS molecules

Copyright (C2021 Huey-wen Chuang, et al.

DOI: https://doi.org/10.37256/acbr.112022725

This is an open-access article distributed under a CC BY license

(Creative Commons Attribution 4.0 International License)

https://creativecommons.org/licenses/by/4.0/ 
generated from impaired metabolic pathways can induce cell damage by modifying the structure of proteins, lipids and nucleic acids [2]. Regardless of its harmful role in the cellular structure, ROS molecules are necessary signals in plant cells to induce an efficient response to counteract environmental stress [3]. Nevertheless, pathogen infection activates ROS production through nicotinamide adenine dinucleotide phosphate (NADPH) oxidase and peroxidases to embark on the signaling pathway of the defense response and reinforce the cell wall structure by lignin deposition [4-5].

Beneficial rhizospheric microbes exert multifaceted effects on plant health and productivity. In addition to improving plant growth by promoting root development and nutrient uptake, many root-colonizing microbes also exhibit probiotic features by suppressing pathogen growth or activating plant induced defense response to reduce disease incidence in host plants [6]. For example, microbes colonizing the root surface were shown to be capable of improving drought tolerance by increasing shoot and leaf biomass and photosynthetic activity in grapevines [7]. Burkholderia phytofirmans PsJN was reported to activate induced resistance against gray mold and to enhance cold stress tolerance by increasing the levels of stress-related metabolites in a low-temperature environment [8]. More studies have shown that volatiles produced by the rhizobacterial strain O6 induce systemic resistance against drought stress in Arabidopsis [9]. Two induced defense response pathways with distinguished signaling molecules are present in plant cells. In comparison to pathogen-triggered systemic acquired resistance (SAR), which requires accumulated salicylic acid (SA) as a mediator signal, microbial metabolites act as elicitors to activate induced systemic resistance (ISR) by stimulating JA or ethylene signaling in targeted plants [10]. More evidence indicates that the interaction in the cellular responses is required for abiotic and biotic stress tolerance. For example, metabolic pathways are involved in cell wall strengthening functions for both abiotic and biotic stress tolerance [11]. The expression of EDR15 was rapidly induced under drought stress; overexpression of this gene resulted in increased resistance against the bacterial necrotroph Erwinia carotovora subsp. carotovora in Arabidopsis [12]. JA and its derivatives play essential roles in plant defense against biotic stresses, such as pathogens and herbivory [13-14]. However, JA induces the expression of C-repeat binding factors (CBFs) to regulate the acclimation to freezing stress in Arabidopsis [15]. The transcription factor CBF-dependent pathway and its upstream Inducer of CBF Expression (ICE) including ICE1 and ICE2, play central roles in the cellular regulation of cold acclimation [16].

Phalaenopsis orchids, native to tropical Asian countries, are one of the most economically important potted flowers in Taiwan. In this study, the metabolites of P. aeruginosa strain Y1 (Y1M) exhibited the activities of metal chelating and reducing power. Treatment with Y1M altered physiological activities related to stress responses in Phalaenopsis leaf tissues. Orchid plants treated with Y1M showed increased tolerance to cold stress and resistance against Erwinia chrysanthemi, a pathogen of bacterial soft rot. Y1M activated Phalaenopsis genes involved in diverse cellular pathways, including growth, cold stress acclimation, and induced defense responses.

\section{Materials and methods}

\subsection{Bacterial strain characterization}

One gram of compost dissolved in $100 \mathrm{~mL}$ of sterilized water was serially diluted to concentrations ranging from $10^{4}$ to $10^{6}$ and plated on nutrient agar (NA) medium containing $0.3 \%(\mathrm{w} / \mathrm{v})$ beef extract and $0.5 \%(\mathrm{w} / \mathrm{v})$ peptone. Bacterial cultures were incubated at $28^{\circ} \mathrm{C}$. A single colony was selected for bacterial genomic DNA isolation and polymerase chain reaction (PCR) amplification following the methods described in Sukkasem et al. [17]. The fD1 and rP1 primers were used for detecting 16S rDNA [18]. The PCR fragments were sequenced and analyzed using the Basic Local Alignment Search Tool (BLAST) program [19].

\subsection{Analyses of metal chelating activity and reducing the power of bacterial metabolites}

Analysis of the iron chelating activity was carried out following the methods described by Decker and Welch [20]. A total of $0.5 \mathrm{~mL}$ of bacterial culture supernatant was added to $0.05 \mathrm{~mL}$ of $2 \mathrm{mM} \mathrm{FeCl}_{2}$ and $0.1 \mathrm{~mL}$ of $5 \mathrm{mM}$ ferrozine. This mixture was incubated at $40^{\circ} \mathrm{C}$ for $10 \mathrm{~min}$, after which the absorbance at $562 \mathrm{~nm}$ was measured. The chelation rate (\%) was calculated using the following equation: $\left(A_{0}-\left(A_{1}-A_{2}\right)\right) / A_{0} \times 100$. In this equation, $A_{0}, A_{1}$, and $A_{2}$ represent the absorbance of the control, the sample, and the blank, respectively. The methods described by Kim et al. [21] were 
followed for analysis of the reducing power. A total of $1.0 \mathrm{~mL}$ of bacterial supernatant was mixed with $1.0 \mathrm{~mL}$ of 0.2 M sodium phosphate buffer $(\mathrm{pH} 6.6)$ and $1.0 \mathrm{~mL}$ of $1 \%$ potassium ferricyanide $(\mathrm{w} / \mathrm{v})$, followed by incubation at $50^{\circ} \mathrm{C}$ for $20 \mathrm{~min}$. After incubation, an equal volume of $10 \%$ trichloroacetic acid (TCA) was added to the reaction; then, 3.0 $\mathrm{mL}$ of supernatant collected by centrifugation at $3000 \mathrm{rpm}$ for 10 min was mixed with $0.6 \mathrm{~mL}$ of $0.1 \% \mathrm{FeCl}_{3}$, followed by incubation at room temperature for $10 \mathrm{~min}$. The absorbance of the mixture was measured at $700 \mathrm{~nm}$. Butylated hydroxyanisole (BHA) $(20 \mathrm{mM})$ and $\mathrm{H}_{2} \mathrm{O}$ were used as positive and negative controls, respectively. These experiments were performed in triplicate.

\subsection{Growth analyses and cold stress treatment in Phalaenopsis orchids}

Phalaenopsis Sogo Yukidian cultivar V3 in a $4.5 \mathrm{~cm}$ pot size was used for treatments. Bacterial metabolites were prepared by filtration $(0.45 \mu \mathrm{m}$ pore size membrane) of the bacterial culture in medium containing $0.5 \%(\mathrm{w} / \mathrm{v})$ sucrose, $0.5 \%(\mathrm{w} / \mathrm{v})$ peptone, $0.5 \%(\mathrm{w} / \mathrm{v}) \mathrm{MgSO}_{4}, 0.04 \%(\mathrm{w} / \mathrm{v}) \mathrm{KH}_{2} \mathrm{PO}_{4}, 0.03 \%(\mathrm{w} / \mathrm{v}) \mathrm{K}_{2} \mathrm{HPO}_{4}$, and $0.5 \%(\mathrm{w} / \mathrm{v})$ yeast extract. The resultant filtrate was used for orchid treatments. Phalaenopsis plants were treated with bacterial metabolites once a week for 4 consecutive weeks. Leaf tissues of the control and treated orchids were harvested for analyses, including the total sugar, enzyme activities of antioxidant enzymes, such as CAT, APX and PAL, and the lignin content. Phalaenopsis orchids treated with bacterial metabolites for 4 weeks were subjected to cold treatment by incubating the plants at $10^{\circ} \mathrm{C}$ for 3 weeks. At the end of cold stress treatment, the area of necrotic tissues was recorded, and analysis of MDA and electrolyte leakage was conducted. Fifteen plants were included in each treatment. Experiments were performed in triplicate.

\subsection{Determining the total sugar contents in Phalaenopsis orchids}

The total sugar contents were examined using the anthrone method [22]. Phalaenopsis tissues were ground in $80 \%$ ethanol, and ethanol was removed in boiling water. The total sugar was dissolved in the anthrone solution $(0.4 \%$ in $\mathrm{H}_{2} \mathrm{SO}_{4}$ ) and boiled for $10 \mathrm{~min}$. Optical densities for each sample were measured at a wavelength of $620 \mathrm{~nm}$, and total sugar concentrations were determined based on the glucose standard curve.

\subsection{Analyses of CAT, APX and PAL Activities in Phalaenopsis orchids}

The leaf tissues of Phalaenopsis orchids were homogenized in $50 \mathrm{mM}$ potassium phosphate buffer $(\mathrm{pH} 7.0)$ containing $1 \%$ polyvinylpyrrolidone (PVP) and $0.1 \mathrm{mM}$ Ethylenediaminetetraacetic acid (EDTA). Supernatants were used for the analysis of the CAT activity following the methods described by Aebi and Lester [23]; in brief, $0.5 \mu \mathrm{L}$ of supernatant was added to $1 \mathrm{~mL}$ of a reaction solution containing $0.1 \% \mathrm{H}_{2} \mathrm{O}_{2}, 0.1 \mathrm{mM}$ EDTA and $100 \mathrm{mM}$ potassium phosphate buffer ( $\mathrm{pH}$ 7.0). The reaction was performed for $3 \mathrm{~min}$ at room temperature, and the absorbance at $240 \mathrm{~nm}$ was recorded. The CAT activity was expressed as the amount ( $\mu$ mole) of $\mathrm{H}_{2} \mathrm{O}_{2}$ decomposed in one minute with one gram of fresh tissue. The APX activity was determined following the methods described by Nakano and Asada [24]; briefly, $50 \mu \mathrm{L}$ of supernatant was added to a reaction solution containing $50 \mathrm{mM}$ potassium phosphate buffer (pH 7.0), 2 $\mathrm{mM} \mathrm{H}_{2} \mathrm{O}_{2}$, and $2 \mathrm{mM}$ ascorbate. The reaction was measured based on the absorbance at $290 \mathrm{~nm}$. One unit of APX was determined by monitoring the rate of decrease in ascorbate at A290 $\left(\varepsilon=2.8 \mathrm{mM}^{-1} \mathrm{~cm}^{-1}\right)$. For the analysis of PAL, the procedure described by Redman et al. [25] was adopted. Briefly, the leaf tissues of Phalaenopsis orchids were extracted in $0.01 \mathrm{mM}$ sodium phosphate buffer $/ 0.01 \mathrm{M}$ potassium phosphate buffer $(\mathrm{pH}$ 6.0). The supernatant was added to a reaction solution containing $6 \mu \mathrm{M} \mathrm{L}$-phenylalanine and $0.05 \mathrm{M}$ Tris- $\mathrm{HCl}$ buffer $(\mathrm{pH}$ 8.0). The reaction was performed at $37^{\circ} \mathrm{C}$ for 1 hour, and the absorbance at $290 \mathrm{~nm}$ was measured. PAL activity was expressed as $\mathrm{mg}$ of cinnamic acid per mg of protein per hour.

\subsection{Analysis of lignin contents in Phalaenopsis orchids}

The method described by Bruce and West [26] has been adopted to measure the lignin content in Phalaenopsis orchids. Phalaenopsis tissues were homogenized in a solution containing $100 \mathrm{mM}$ phosphate buffer $(\mathrm{pH} 7.4)$ and $0.5 \%$ Triton X-100. The pellet was collected by centrifugation, washed with $95 \%$ ethanol, and then dried at $60^{\circ} \mathrm{C}$. Ten 
milligrams of dry powder were added to a reaction solution containing $1.5 \mathrm{~mL}$ of $2 \mathrm{~N} \mathrm{HCl}$ and $0.3 \mathrm{~mL}$ of thioglycolic acid (TGA). This reaction was incubated at $95^{\circ} \mathrm{C}$ for 4 hours. One milliliter of $0.5 \mathrm{~N} \mathrm{NaOH}$ was then added, and the sample was incubated at room temperature for 16 hours. Centrifugation was then performed to collect the supernatant. A total of $0.9 \mathrm{~mL}$ of supernatant was treated with $0.3 \mathrm{~mL}$ of $2 \mathrm{~N} \mathrm{HCl}$ and incubated at $4^{\circ} \mathrm{C}$ overnight. The pellet collected by centrifugation was dissolved in $0.5 \mathrm{~N} \mathrm{NaOH}$, and the absorbance at $280 \mathrm{~nm}$ was measured. The lignin content was calculated from a linear calibration curve made from commercial lignin (Sigma-Aldrich).

\subsection{Analysis of MDA and electrolyte leakage}

The procedures described by Heath and Packer [27] were adapted for MDA quantification. Phalaenopsis tissues were ground in a solution containing $0.25 \%$ thiobarbituric acid (TBA) and $10 \%$ trichloroacetic acid (TCA). This extract was heated to $95^{\circ} \mathrm{C}$ for $15 \mathrm{~min}$, and the absorbance of the supernatants was determined at 532 and $600 \mathrm{~nm}$. The MDA concentration $(\mathrm{mM})$ was calculated using the following equation: $\left(\mathrm{OD}_{532}-\mathrm{OD}_{600}\right) / 155$. The measurement of electrolyte leakage was performed by following the procedures described by Dionisio-Sese and Tobita [28]. In brief, Phalaenopsis tissues incubated in $10 \mathrm{~mL}$ of $\mathrm{H}_{2} \mathrm{O}$ at $32^{\circ} \mathrm{C}$ for 2 hours were examined for the first electrical conductivity (EC1) using a conductivity meter (inoLAB Cond 720). Following the determination of EC1, these tissues were autoclaved, and the second electrical conductivity (EC2) was measured. The percentage of electrolyte leakage was expressed as (EC1/EC2) $\times 100 \%$.

\subsection{Analysis of soft rot disease resistance in Phalaenopsis orchids}

A total of $1 \times 10^{4} \mathrm{CFU} / \mathrm{mL} E$. chrysanthemi was inoculated onto filter paper located on the upper surface of Phalaenopsis leaves pretreated with Y1M and control leaves. Pretreatments were conducted by spraying Y1M on Phalaenopsis Sogo Yukidian cultivar V3 in a $4.5 \mathrm{~cm}$ pot size once every 2 days for a total of 3 times. Two days after inoculation of E. chrysanthemi, inoculant spots surrounded by decomposed tissue were scored as infected spots. Infection rates were calculated by dividing the number of infected spots by the total number of inoculant spots in individual plants. Fifteen plants were included in each treatment. Experiments were performed in triplicate.

\subsection{Phalaenopsis protein extraction and Western blot analyses}

Proteins were extracted from the leaf tissues of Phalaenopsis orchids using the methods described by Wang et al. [29]. In brief, Phalaenopsis tissues were ground into a fine powder, and extraction was performed using a solution containing equal volumes of phenol and sodium dodecyl sulfate (SDS) buffer composed of $30 \%$ sucrose, $2 \%$ SDS, 0.1 $\mathrm{M}$ Tris- $\mathrm{HCl}$, and $5 \%$ b-mercaptoethanol at $\mathrm{pH}$ 8.0. The supernatant was precipitated using a $2.5 \mathrm{x}$ volume of methanol and $0.1 \mathrm{M}$ ammonium acetate $\left(\mathrm{CH}_{3} \mathrm{CO}_{2} \mathrm{NH}_{4}\right)$. For Western blot analysis, $15 \mu \mathrm{g}$ of total protein was separated on $10 \%$ SDS-PAGE gels. Polyclonal antibodies against CAT, L-ascorbate peroxidase (APX), b-1, 3-glucanase (PR-2), class I chitinase (PR-3), and chloroplastic lipoxygenase (LOX-C) were used for hybridization. All the antibodies were purchased from Agrisera. The hybridization images were captured with a Chemi-Smart 5000 (Vilber Lourmat).

\subsection{Phalaenopsis RNA extraction and RNA-seq analysis}

The leaf tissues of the control and Phalaenopsis Sogo Yukidian cultivar V3 treated with PaY1M were harvested for RNA extraction using the RNeasy Plant Mini Kit (QIAGEN). Five micrograms of the total RNA were used for polyA-plus RNA purification using poly-Toligo-attached beads. The purified mRNA was fragmented and used for the synthesis of cDNA using random primers; furthermore, second-strand cDNA was synthesized using DNA polymerase I and RNaseH. Paired-end RNA-seq libraries were constructed and sequenced on the Illumina HiSeq4000 platform. The raw sequencing data were processed to remove adaptor and low-quality sequences through the Illumina pipeline. The 75-mer sequences of cDNA were aligned to the Phalaenopsis genome sequence annotated in Phalaenopsis aphrodite (assembly ASM301322v1) using the Bowtie2 tool [30]. Gene expression values were calculated based on fragments per kilobase of exons per million reads (FPKM), and genes that were differentially expressed between the two groups of samples were identified using the RNA-Seq by Expectation-Maximization (RSEM) software program [31]. Genes 
with an estimated absolute log2-fold change (FC) larger than 1 and a false discovery rate (FDR) less than 0.05 were considered significantly different [31].

\subsection{Statistical analysis}

The differences between the treatments were analyzed with the SAS program (version 3.71) using ANOVA and Tukey's test in which a $\mathrm{P}$ value less than 0.05 was considered significantly different.

\section{Results}

\subsection{Characterization of the isolated bacterial strain}

A PCR fragment of $1400 \mathrm{bp}$ was amplified from the genomic DNA of a newly isolated bacterial strain using primers specific to the 16S rDNA. The obtained DNA fragment was sequenced and analyzed using the BLAST program [19]. Sequence analysis of the newly isolated bacterial strain Y1 showed 100\% identity to 8 Pseudomonas aeruginosa strains and $99 \%$ identity to 2 Pseudomonas spp. strains (Table1). Further characterization of the potential bioactivity of this isolated strain showed that Y1M exhibited a strong metal chelating capacity (Figure 1a) and moderate ferric reducing power (Figire $1 \mathrm{~b}$ ).

Table 1. Characterization of Pseudomonas aeruginosa strains Y1

BLAST results of the $16 \mathrm{~S}$ rDNA sequence of $P$. aeruginosa strain Y1 showing 100 to $99 \%$ identity to various Pseudomonas strains

\begin{tabular}{ccc}
\hline Bacterial strains & GenBank ID & Identity (\%) \\
\hline Pseudomonas aeruginosa strain LZS8436 & MF143547 & 100 \\
Pseudomonas aeruginosa strain JQ-41 & KM948588 & 100 \\
Pseudomonas aeruginosa strain ALK320 & KC456535 & 100 \\
Pseudomonas aeruginosa strain HNYM11 & JN999889 & 100 \\
Pseudomonas aeruginosa strain S2QPS8 & HQ844502 & 100 \\
Pseudomonas aeruginosa strain NA137 & KT005274 & 100 \\
Pseudomonas aeruginosa strain DSPV 005PSA & JQ322234 & 100 \\
Pseudomonas aeruginosa strain HK 1-3 & JN661696 & 100 \\
Pseudomonas sp. strain ZNW & MK368450 & 99 \\
Pseudomonas sp. strain Y & MF419261 & 99
\end{tabular}
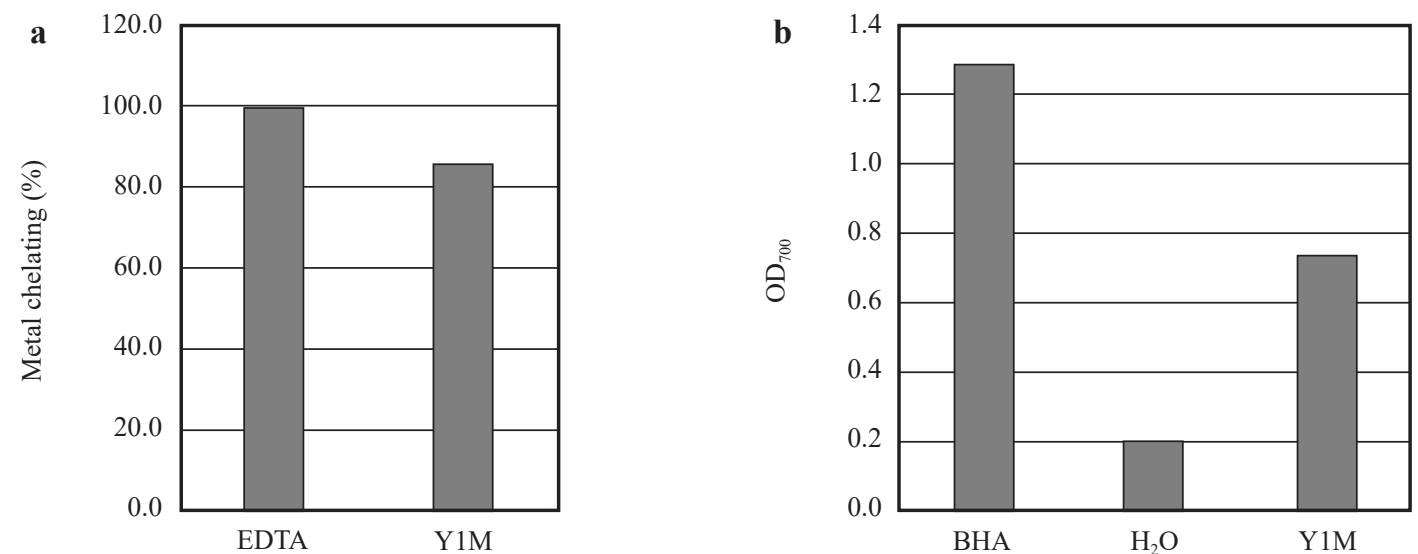

Figure 1. Characterization of Pseudomonas aeruginosa strains Y1.(a) The metal chelating activity of Y1 supernatants and a positive control of 1 mM EDTA. (b) The ferric reducing power of $\mathrm{Y} 1$ supernatants. Butylated hydroxyanisole (BHA) (20 mM) and $\mathrm{H}_{2} \mathrm{O}$ were used as positive and negative controls, respectively 


\subsection{Stress-related physiologies of Phalaenopsis orchids induced by Y1M treatments}

Phalaenopsis orchids were treated with Y1M once a week for 4 consecutive weeks. Our results showed that Y1M increased the total sugar contents in the Phalaenopsis leaf tissues (Figure 2a) and the activities of antioxidant enzymes, including CAT and APX (Figure $2 \mathrm{~b}$ and $\mathrm{c}$ ). Furthermore, the enzyme activity of PAL and the lignin content were increased in response to Y1M treatment (Figure $2 \mathrm{~d}$ and e). The antioxidant defense system plays a significant role in the regulation of the stress response [32]. Cell wall strengthening by lignin deposition is an effective cellular regulation associated with stress tolerance in both abiotic and biotic stress responses [11]. Moreover, PAL is a key enzyme involved in the synthesis of secondary metabolites correlated with defense responses, such as flavonoids, phytoalexins, and lignin [33]. Consistently, Y1M treatment increased the protein accumulation associated with ROS scavenging, such as CAT and APX, and disease resistance, such as the pathogenesis-related proteins PR-2 and PR-3 (Figure 2f). More increased protein was detected in the Y1M-treated Phalaenopsis tissues in which LOX protein levels were higher in the treated tissues than in the control tissues (Figure 2f). LOX is involved in the synthesis of oxylipins, including JA [34]. These results suggested that Y1M treatment was able to activate cellular pathways related to JA synthesis, ROS scavenging, and disease resistance in Phalaenopsis orchids.
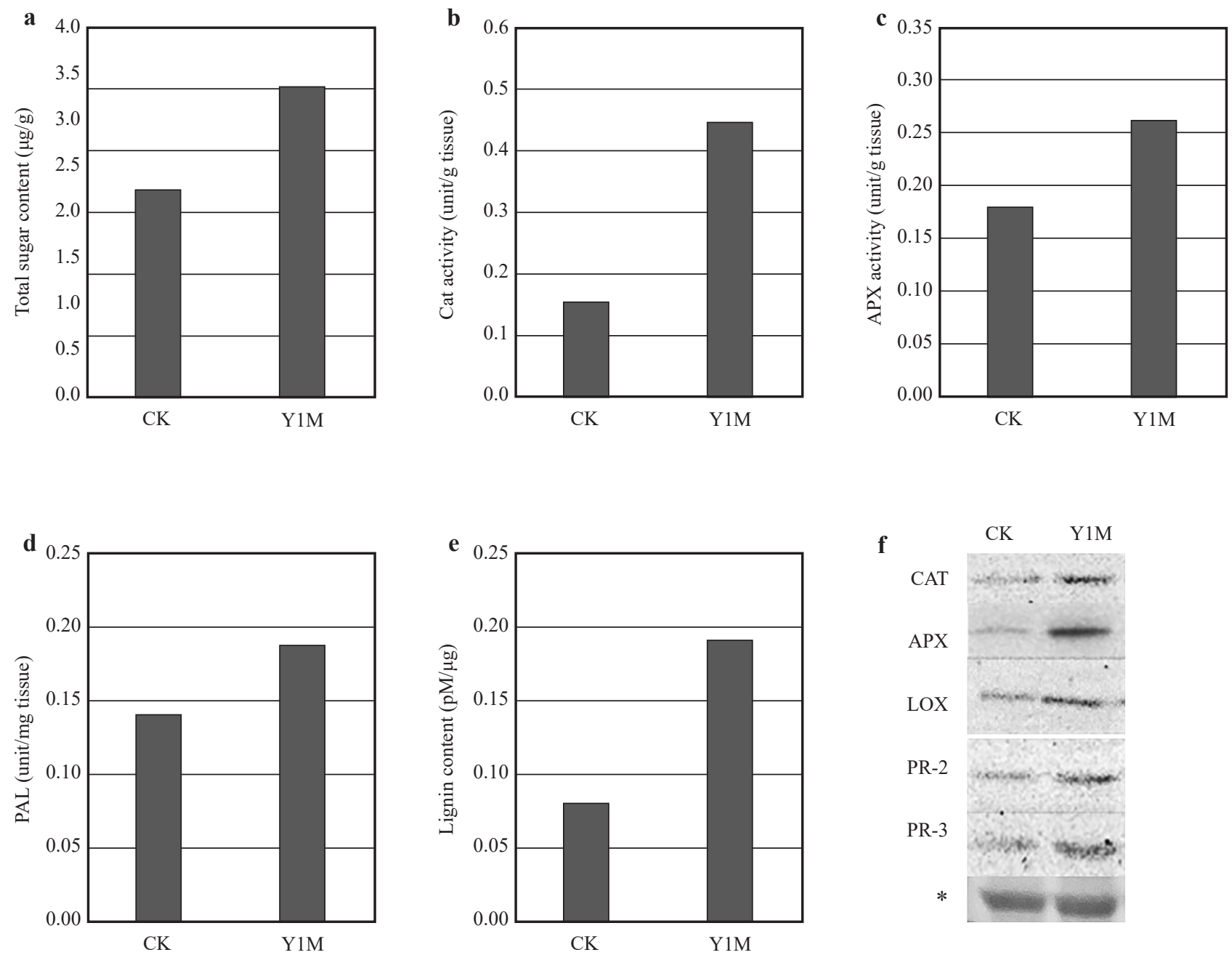

Figure 2. Physiological alterations of Phalaenopsis orchids in response to Y1M treatment. Leaf tissues of Phalaenopsis orchids were harvested for analyses of the total sugar contents (a), activities of CAT (b), APX (c), PAL (d), and lignin contents (e). Total proteins extracted from Phalaenopsis tissues treated with Y1M were used for Western blot analyses using hybridization antibodies specific to CAT, APX, and LOX; the star ( $*$ ) indicates ponceau staining gels to check for equal loading of proteins in each lane 


\subsection{PaY1 treatment enhanced the cold stress tolerance in Phalaenopsis orchids}

Phalaenopsis orchids are tropical plant species whose growth activity is susceptible to low temperatures that grow in an environment where temperatures are below $15^{\circ} \mathrm{C}$ and may develop physiological disorders related to chilling injury [35]. In this study, Phalaenopsis orchids pretreated with Y1M were exposed to a growth temperature of $10^{\circ} \mathrm{C}$ for 3 weeks under 16 hours of lighting. As shown in Figure 3a, after 3 weeks of low temperature treatment, the leaves of control plants developed a large area of necrotic tissues compared with the Y1M-treated orchids. Moreover, after cold treatment, the leaf tissues of the Y1M-treated orchids obtained lower amounts of MDA and a lower percentage of electrolyte leakage than the control orchids (Figure $3 b$ and c).
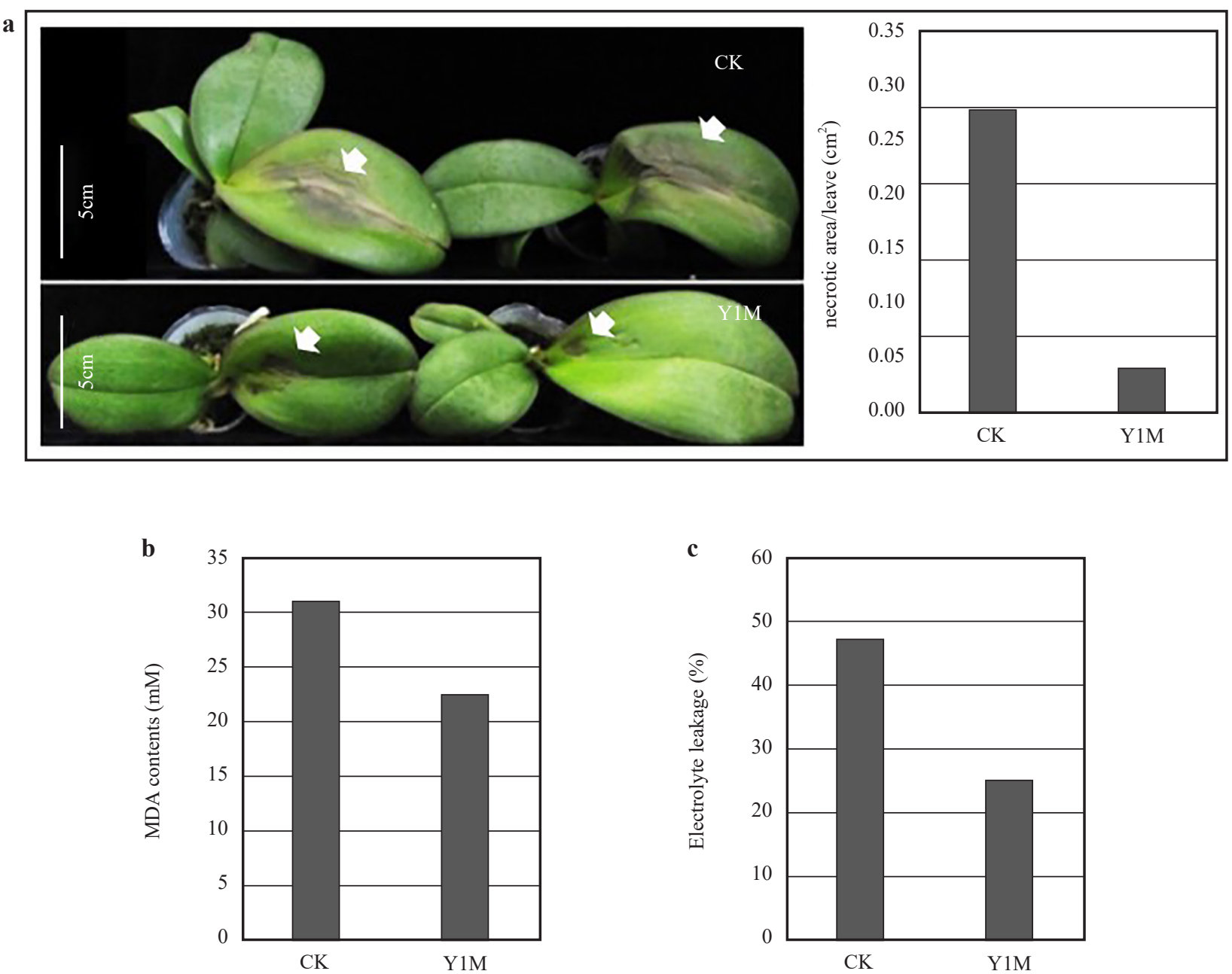

Figure 3. Y1M treatment increased tolerance to low temperature in Phalaenopsis orchids. The phenotype and areas of necrotic tissues developed in the leaf tissues of the Phalaenopsis orchids of the control and Y1M-treated plants after cultivation at $10^{\circ} \mathrm{C}$ for 3 weeks (a). The white arrows indicate the necrotic tissues present on the leaf surfaces. The MDA contents (b) and electrolyte leakage percentage (c) of low-temperature-treated Phalaenopsis leaf tissues were analyzed

\subsection{Y1M treatment reduced the disease incidence of bacterial soft rot in Phalaenopsis orchids}

Bacterial soft rot caused by E. chrysanthemi is a devastating disease in Phalaenopsis orchids in tropical climates [36]. In this study, different infection rates were observed in the plants treated with Y1M and controls. Orchid plants 
inoculated with E. chrysanthemi exhibited various degrees of infection symptoms (Figure 4a). The quantification of the infection rate was calculated by dividing the number of infected spots and the appearance of water-soaked tissues surrounding the inoculation filters by the total number of inoculation spots (Figure 4a). Infection incidence is presented as the mean infection rate plus/minus the standard deviation (SD) from a population of 15 individuals. Our results showed that the infection incidence of Y1M-treated plants was significantly reduced compared to that of control plants (Figure 4b).

a

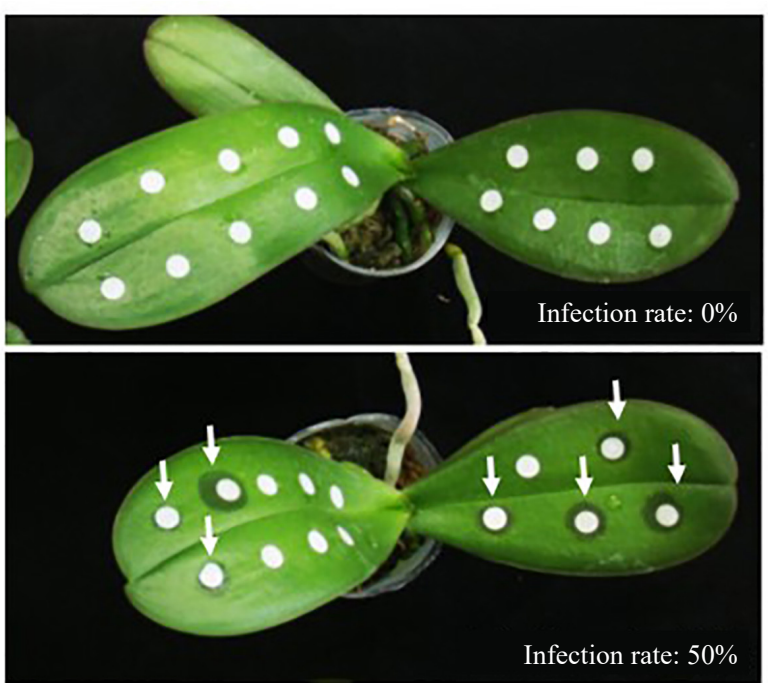

b

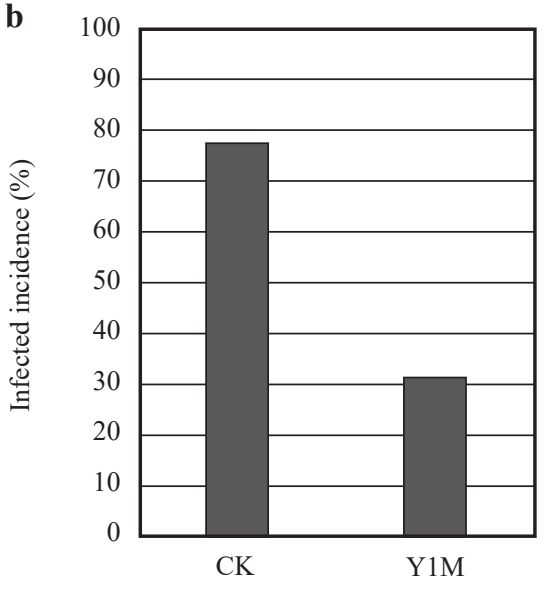

Figure 4. Y1M treatment increased disease resistance against bacterial soft rot in Phalaenopsis orchids. Filter discs containing Erwinia chrysanthemi at $1 \times 10^{4} \mathrm{CFU} / \mathrm{mL}$ were placed on the leaf surfaces of Phalaenopsis orchids. Infection rates were calculated by dividing the number of infected spots, which were scored by the appearance of water-soaked tissues surrounding the inoculant spots (indicated by white arrows), by the total number of inoculant spots in individual plants (a). Infection incidence is presented as the mean infection rate plus-minus standard deviation (SD) from a population of 15 individuals (b)

\subsection{Stress-related cellular pathways regulated by PaY1 in Phalaenopsis orchids}

The results of this study showed that Y1M treatment increased the tolerance toward chilling stress and increased the resistance against bacterial soft rot in Phalaenopsis orchids. To gain insights into the molecular mechanisms underlying the effectiveness of Y1M in improving stress tolerance, transcriptome alterations of Phalaenopsis orchid in response to Y1M treatment were analyzed by RNA-Seq. Upregulated genes with induced $\mathrm{FC} \operatorname{larger}_{\text {than }} \log _{2}[\mathrm{FC}]$ $>2$ were investigated. Among the Y1M upregulated genes, genes that exhibited annotated functions associated with cellular pathways related to ROS, RNAi regulation, and hormone synthesis/perception were identified (Figure 5a). Detailed information on the upregulated genes is shown in Figure 5b. Y1M increased the expression of genes coding for respiratory burst oxidase homolog (Rboh) proteins functioning in the generation of apoplastic ROS in response to pathogen attack [37]. Upregulated genes also comprised gene coding for CASP-LIKE, allantoinase, and SRC2like, whose functions are involved in the regulation of ROS channeling, acting as ROS sensors and ROS activators, respectively [38-40]. Additionally, Y1M activated genes, such as heme oxygenase 1 (HO1) and catalase functioning in the $\mathrm{H}_{2} \mathrm{O}_{2}$-mediated signaling pathway, are required for stressful tolerance and ROS scavenging, respectively [41-42]. Transcription factors implicated in the regulation response to oxidative stress were also identified, such as TCP13 and 15, Zm1, and NAC92. The activity of the TCP transcription factor family is redox sensitive [43]. Transcription factor $\mathrm{Zm} 1$ is involved in the transcriptional regulation of anthocyanin synthesis [44]. Anthocyanin is a flavonoid compound that plays an antioxidant role in the plant defense response [45]. The transcription factor NAC domain-containing protein 92 exhibits multiple functions, including the regulation of lateral root development and a regulatory network that may involve cross-talk with salt-and $\mathrm{H}_{2} \mathrm{O}_{2}$-dependent signaling pathways [46-47]. Y1M increased the expression of several members of the ARGONAUTE (AGO) family, a group of genes related to the cellular pathway of regulatory 
RNA. Among them, 3 members of $A G O 1$ were upregulated by Y1M (Figure 5b). $A G O 1$ was proven to be functionally involved in the miR408-mediated regulation of plantacyanin [48]. An upregulated gene coding for a blue copper binding $\mathrm{p}(\mathrm{BCB})$ protein, plantacyanin, was found in the Phalaenopsis transcriptome (Figure 5b). AGO 4 has been implicated in resistance against Fusarium brachygibbosum infection through regulation of JA in wild tobacco [49].

b Acc. No. $\log _{2}[\mathrm{FC}]$ Description

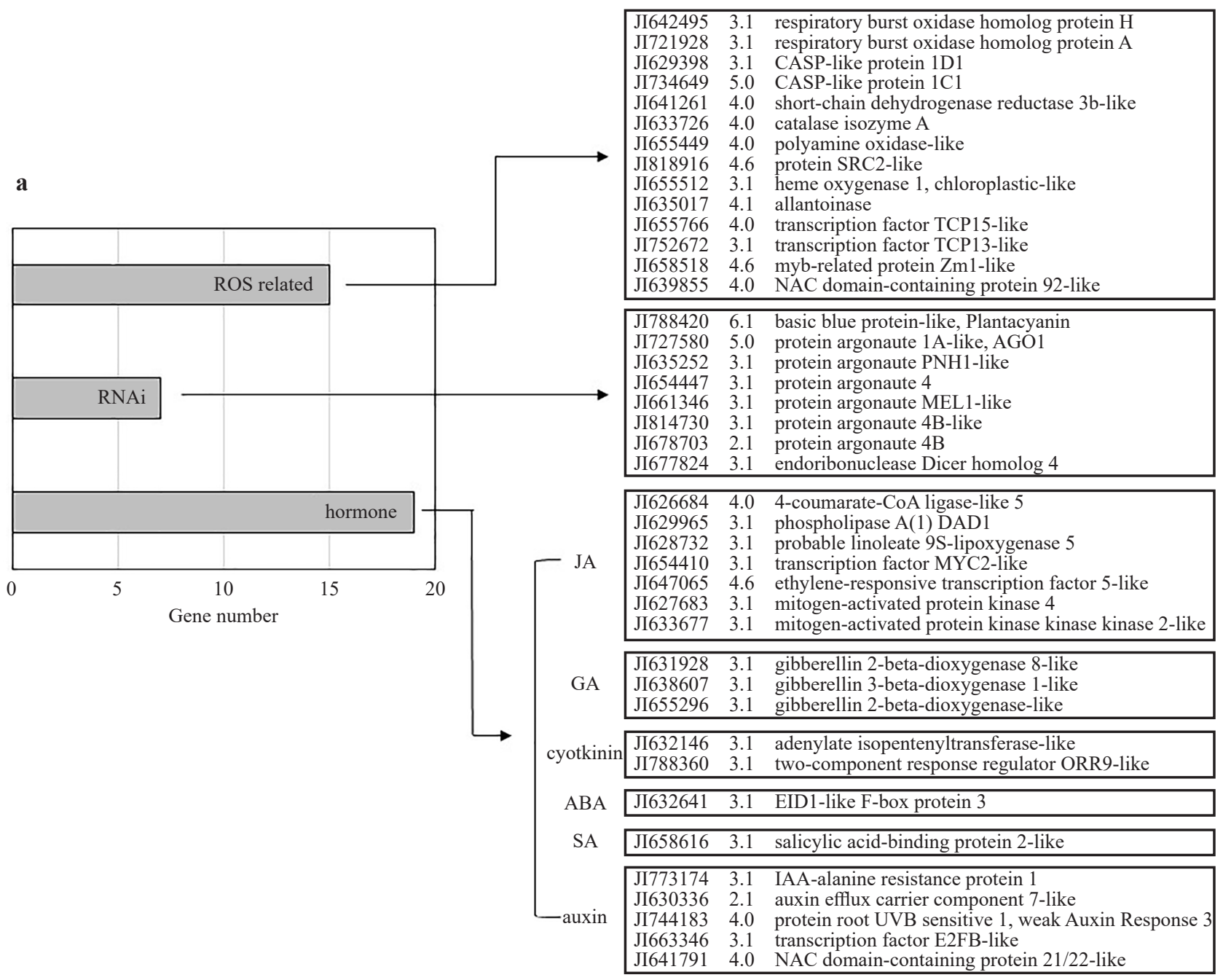

Figure 5. Upregulated genes related to the synthesis of signaling molecules identified in the Phalaenopsis transcriptome in response to Y1M treatment. (a) Upregulated genes with functional annotations classified as regulation of reactive oxygen species (ROS) homeostasis, the RNAi regulation pathway, and hormone synthesis/perception. (b) Information on upregulated genes, including the accession number (Acc. No.), induction folds expressed as $\log _{2}[\mathrm{FC}]$, and gene description-related signaling pathways of ROS, RNAi and hormone regulation, including JA, GA, cytokinin, ABA, SA, and auxin

\subsection{Y1M activated hormone signaling pathways in Phalaenopsis orchids}

Y1M treatment also activated a group of genes related to several hormones signaling pathways, including JA, GA, cytokinin, ABA, SA, and auxin; among them, genes involved in the JA signaling pathway constitute the largest group in this gene category (Figure 5b). Y1M activated genes are involved JA biosyntheses, such as 4CLL5, DAD1, and LOX1.5 [50-52], JA signal transduction, such as $M Y C 2$ [53], and protein kinases are involved in JA-mediated defense responses, such as mitogen-activated protein kinase (MAPK) 4/2, which participates in the protein phosphorylation required for JAmediated defense gene expression [54]. In addition, ethylene-responsive transcription factor (ERF5)-like is a positive 
regulator of JA/ethylene-mediated defense [55]. Moreover, EID1-like F-box protein 3 and salicylic acid-binding protein 2-like are involved in the ABA and SA signaling pathways, respectively [56-57]. Upregulated genes also comprised IAA-alanine resistance protein 1 and weak auxin response 3 for auxin response [58], auxin efflux carrier component 7-like for auxin transport, and transcription factors, including E2FB-like, for auxin-mediated cell division [59] and NAC domain-containing protein 21/22-like, which is involved in auxin-regulated lateral root development [60]. Nevertheless, upregulated genes constituted gibberellin 2-beta-dioxygenase and gibberellin 3-beta-dioxygenase, which are involved in both catabolic and anabolic regulation of GA synthesis [61], and adenylate isopentenyltransferase-like and twocomponent response regulator ORR9-like, for cytokinin synthesis and negative regulation of cytokinin signaling [6263]. These results indicated that Y1M treatment exerted a substantial effect on JA synthesis and signaling pathways and showed positive correlations with ABA, SA and auxin signaling pathways.

\subsection{Y1M-activated gene expression is involved in biotic and abiotic stress tolerance}

Y1M also activated Phalaenopsis gene expression associated with responses toward biotic and abiotic stresses and cell wall modification (Figure 6a). Among them, cellular pathways, including regulation of pattern-triggered immunity (PTI) and hypersensitive response (HR), synthesis of pathogenesis-related (PR) proteins and callose, and disease resistance genes constituted the biotic stress response in the Y1M-treated orchid plants (Figure 6a). Detailed gene information is indicated in Figure 6b. Y1M treatment increased the expression of Phalaenopsis genes implicated in PTI,

b Acc. No. $\log _{2}[\mathrm{FC}]$ Description

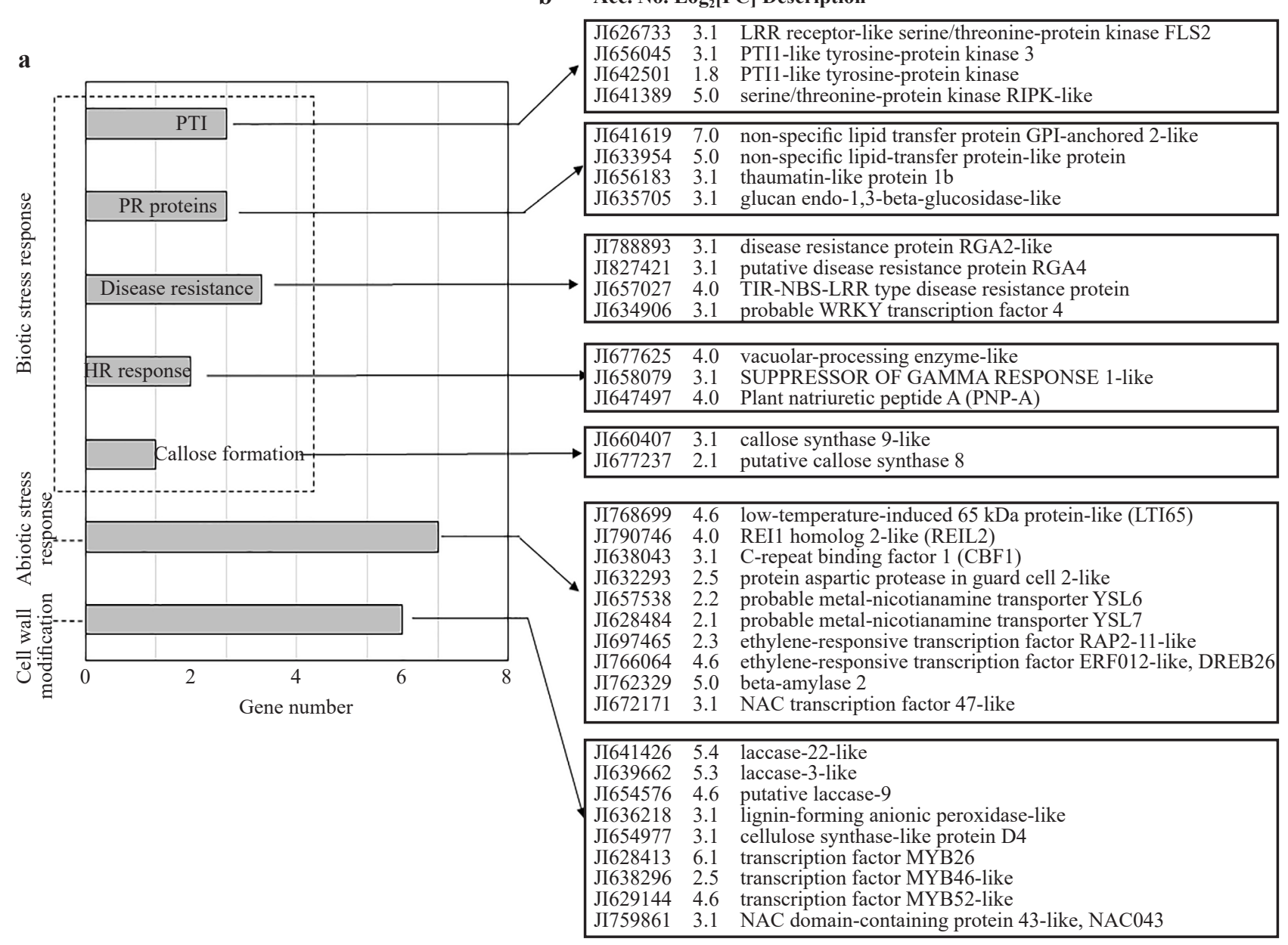

Figure 6. Upregulated genes related to the cellular pathways of stress response identified in the Phalaenopsis transcriptome in response to Y1M treatment. (a) Upregulated genes related to the cellular pathways of responses to biotic and abiotic stresses and regulation of cell wall modification. The biotic stress response gene group was divided into subgroups of PAMP-triggered immunity (PTI), pathogenesis-related (PR) protein synthesis, 
disease resistance genes, and hypersensitive response (HR). (b) Information on the upregulated genes corresponding to the gene groups listed in (a) which comprise the LRR receptor-like kinases FLAGELLIN SENSITIVE 2 (FLS2), PTI1-like tyrosine-protein kinase 3, and serine/threonine-protein kinase RIPK-like [64-65]. Apart from these, Figure 6b shows that Y1M activated genes comprising several PR proteins, such as nonspecific lipid transfer protein, haumatin-like protein and glucan endo-1,3beta-glucosidase-like [66], disease resistance genes, such as disease resistance gene analogs (RGAs) and TIR-NBS-LRRTIR type proteins [67-68], and genes related to HR, such as vacuolar-processing enzyme-like isoforms, suppressor of gamma response 1 ( $\operatorname{sog} 1)$-like isoform, and plant natriuretic peptide A [69-71] (Figure 6b). Furthermore, Y1M increased the expression of the gene coding for the synthesis of callose, a physical barrier to slow pathogen invasion [72] (Figure $6 \mathrm{~b})$. Y1M treatment increased the expression of genes involved in tolerance to various abiotic stresses. Upregulated genes for the cold stress response were low-temperature-induced $65 \mathrm{kDa}$ protein, REII homolog 2-like (REIL2), C-repeat binding factor 1 (CBF1), and beta-amylase 2 [73-75]. Upregulated genes have functions in drought tolerance, such as protein aspartic protease in guard cell 2-like [76], in the regulation of ion homeostasis, such as metal-nicotianamine transporter YSLs and RAP2-11 [77-78], and in waterlogged tolerance, such as NAC transcription factor 47 [79] (Figure 6b). Moreover, the expression of ERF012-like, also named DREB26, has been shown to be regulated under stressful environments [80] (Figure 6b). The cell wall structure plays a significant role in the plant defense response against various pathogens and plant tolerance to various abiotic stresses [11]. Figure $6 \mathrm{~b}$ shows that $\mathrm{Y} 1 \mathrm{M}$ treatment increased the expression of genes coding proteins involved in cell wall synthesis, such as cellulose synthase-like protein D4, and in cell wall lignification, such as laccases and lignin-forming anionic peroxidase-like [81-82]. Moreover, Y1M activated the expression of transcription factors that are implicated in the regulation of the secondary cell wall, including $M Y B 26$, MYB46-like, MYB52, and NAC domain-containing protein 43-like (NAC043) [83-86] (Figure 6b).

\section{Discussion}

Soft rot disease caused by E. chrysanthemi infection has become a significant disease that causes severe losses in Phalaenopsis production [36]. Cold stress exerts a significant physiological impact on tropical crops. Pseudomonas spp. produces a wide variety of biologically active compounds, which may act as plant defense stimulators [87]. Beneficial microbes produce various metabolites to elicit a comprehensive response in plant cells to alter plant growth activity. Among them, altered hormone homeostasis and perception in the targeted plants are important factors in plant growthpromoting events mediated by microorganisms [88]. In this study, we characterized the effect of Y1M, a metabolite of $P$. aeruginosa strain $\mathrm{Y} 1$ with strong metal chelating activity, on plant growth to show that $\mathrm{Y} 1 \mathrm{M}$ increased the antioxidant activity and lignin contents in treated Phalaenopsis tissues, simultaneously inducing tolerance toward cold stress tolerance and disease resistance against bacterial soft rot in orchid plants. In addition, Y1M applications increased protein accumulation, including antioxidant enzymes, such as CAT and APX, PR genes, such as PR-2 and PR-3, and JA biosynthesis genes, such as LOX1. JA signaling is an important regulator required for ISR that is triggered by beneficial soil microbes [89]; furthermore, this signaling pathway has a role in the regulation of plant tolerance to abiotic stress [90]. Our transcriptome study further substantiates the involvement of JA signaling in Y1M-induced plant growth and stress tolerance. In this study, Y1M treatments activated Phalaenopsis genes with annotated functions involved in JA biosynthesis, including 4CLL5, DAD1, and LOX1.5 [50-52], JA signaling transduction such as MYC2 [53], and JAmediated defense response such as ERF5-like [55]. Consistent with these findings, upregulated genes are also involved in induced disease resistance, including FLS2, RGA proteins, and various PR proteins [64, 66-67]. Additional evidence for the involvement of JA signaling in Y1M-activated Phalaenopsis orchids showed that upregulated transcription included MAPK4 expression, whose role in induced disease resistance against necrotrophic pathogens is mediated by JA signaling [54]. These results suggest that induced disease resistance mediated by JA signaling contributes to disease resistance against bacterial soft rot in Phalaenopsis orchids, and metabolites of P. aeruginosa strain Y1 are a potent inducer of the JA signaling pathway.

In addition to playing a significant role in the regulation of induced disease resistance, a previous study showed the functional role of JA in the regulation of cold stress tolerance by affecting the expression of the CBF transcription factor [91]. JA also induces the expression of $\mathrm{CBF} 1$ to regulate the acclimation to freezing stress in Arabidopsis [15]. JA signaling exerts a positive effect on abiotic stress tolerance through manipulation of the ROS scavenging system in plant 
cells [92]. Consistent with previous studies, treatment with Y1M enhanced the cold stress tolerance in Phalaenopsis orchids and activated the expression of the CBF1 gene, a cold stress-inducible protein, LTI65R and EIL2, a regulator of leaf development under cold stress [73]. Moreover, biochemical and transcriptional evidence suggested that Y1M treatment increased the antioxidant activity in Phalaenopsis orchids. A study has shown that exogenous JA induced long-lasting resistance against bacterial soft rot in calla lily [93]; moreover, antioxidant activity is correlated with disease resistance against bacterial soft rot in potato [94]. Therefore, metabolites produced by P. aeruginosa strain Y1 induce cold stress tolerance, and disease resistance against bacterial soft rot coincides with JA action in Phalaenopsis orchids.

Metabolites of $P$. aeruginosa strain Y1 increased the expression of MAPK4, a component of the protein phosphorylation pathway involved in plant immunity activated by Rboh-dependent ROS synthesis [95]. The ability to sensitively regulate the ROS balance under various adverse environmental factors is positively correlated with plant viability [1]. Transcriptome findings showed a group of upregulated genes with annotated functions associated with the regulation of ROS homeostasis and components of the miRNA408 regulatory pathway, a regulatory pathway implicated in physiological regulation under iron deficiency $[48,96]$. Plant cells responding to metal deficiency could induce the accumulation of ROS and JA accumulation [97-98]. Our results demonstrated the metal chelating activity of Y1M. Hence, it is evident that treatment with Y1M induced an iron deficiency response to activate ROS and JA signaling in the treated cells. More evidence showing the involvement of the miRNA regulatory pathway in the Y1M-induced defense response showed that increased expression of $A G O 4$ was detected in the orchid transcriptome treated with Y1M. In tobacco cells, $A G O 4$ plays a role in disease resistance against $F$. brachygibbosum infection through the regulation of JA signaling [49]. Hence, our results suggest that metabolites of $P$. aeruginosa strain $Y 1$ are able to activate the miRNA regulatory pathway and cellular pathways mediated by ROS and JA signals to regulate growth activity under cold stress and bacterial infection in Phalaenopsis orchids.

Metabolite phenylpropanoid metabolism plays a significant role in plant defense against biotic and abiotic stresses [99]. The function of cell wall strengthening by deposition of lignin, a derivative product of phenylpropanoid metabolism, in abiotic and biotic stress tolerance has been proven [100-101]. Y1M treatment increased the enzyme activity of PAL, an important enzyme catalyzing the synthesis of precursors for phytoalexins and lignin [102]. Furthermore, the lignin contents were increased in response to Y1M treatment in this orchid plant. Transcriptome results identified genes coding for proteins involved in the modification of the cell architecture, such as laccases, cellulose, and peroxidase, and transcription factors involved in the regulation of biosynthesis of the secondary cell wall, such as MYB26, MYB52-like, MYB46-like and NAC043 [83, 85-86, 103]. The role of JA in lignification of the cell wall has been demonstrated; under wounding stress, JA can derepress transcriptional suppression of lignin synthesis genes and trigger lignin deposition [104]. MYB26 and NAC043 are involved in the regulation of secondary cell wall development in anther dehiscence [83, 86]. In addition, JA signaling functions in controlling the anther dehiscence process [105]. Evidence from this study suggests that the resulting phenotypes related to cold stress tolerance and disease resistance in the Y1M-treated plants were correlated with cell wall strengthening mediated by JA signaling.

In conclusion, metal chelating activity associated with metabolites of $P$. aeruginosa strain Y1 may trigger iron deficiency-like responses to activate JA signaling, antioxidant activity, and cell wall strengthening to increase the resistance to cold stress and bacterial soft rot in Phalaenopsis orchids.

\section{Reference}

[1] Singh S, Tuteja G. Reactive oxygen species and antioxidant machinery in abiotic stress tolerance in crop plants. Plant Physiology and Biochemistry. 2010; 48: 909-930.

[2] Jacobson MD. Reactive oxygen species and programmed cell death. Trends in Biochemical Sciences. 1996; 21: 8386.

[3] Foyer CH, Noctor G. Redox regulation in photosynthetic organisms:signaling, acclimation, and practical implications. Antioxidants and Redox Signaling. 2009; 11: 861-905.

[4] Malinovsky FG, Fangel JU, Willats WG. The role of the cell wall in plant immunity. Frontiers in Plant Science. 2014; 50: 178.

[5] Lamb C, Dixon RA. The oxidative burst in plant disease resistance. Review of Plant Physiology and Plant Molecular Biology. 1997; 480: 251-75. 
[6] Khan N, Bano A, Ali S, Babar A. Crosstalk amongst phytohormones from planta and PGPR under biotic and abiotic stresses. Plant Growth Regulation. 2020; 90: 189-203.

[7] Rolli E, Marasco R, Vigani G, Ettoumi B, Mapelli F, Deangelis ML, et al. Improved plant resistance to drought is promoted by the root-associated microbiome as a water stress-dependent trait. Environmental Microbiology. 2015; 17: 316-31.

[8] Theocharis A, Bordiec S, Fernandez O, Paquis S, Dhondt-Cordelier S, Baillieul F, et al. Burkholderia phytofirmans PsJN primes Vitis vinifera L. and confers a better tolerance to low nonfreezing temperatures. Molecular PlantMicrobe Interactions. 2012; 25: 241-249.

[9] Cho SM, Kang BR, Hee Han S, Anderson AJ, Park JY, Lee YH, et al. 2R, 3R-butanediol, a bacterial volatile produced by pseudomonas chlororaphis O6, is involved in induction of systemic tolerance to drought in arabidopsis thaliana. Molecular Plant-Microbe Interactions. 2008; 21: 1067-1075.

[10] Van Loon LC, Bakker PA, Pieterse CM. Systemic resistance induced by rhizosphere bacteria. Annual Review of Phytopathology. 1998; 36: 453-483.

[11] Kesten C, Menna A, Sánchez-Rodríguez C. Regulation of cellulose synthesis in response to stress. Current Opinion in Plant Biology. 2017; 40: 106-113.

[12] Kariola T, Brader G, Helenius E, Li J, Heino P, Palva ET. Early responsive to dehydration 15, a negative regulator of abscisic acid responses in Arabidopsis1. Plant Physiology. 2006; 142: 1559-1573.

[13] Vijayan P, Shockey J, Lévesque CA, Cook RJ, Browse J. A role for jasmonate in pathogen defense of Arabidopsis. Proceedings of the National Academy of Sciences of the United States of America. 1998; 95: 7209-7214.

[14] Bodenhausen N, Reymond P. Signaling pathways controlling induced resistance to insect herbivores in Arabidopsis. Molecular Plant-Microbe Interactions. 2007; 20: 1406-1420.

[15] Hu Y, Jiang L, Wang F, Yu D. Jasmonate regulates the inducer of cbf expression-C-repeat binding factor/DRE binding factor1 cascade and freezing tolerance in Arabidopsis. Plant Cell. 2013; 25: 2907-2924.

[16] Miura K, Jin JB, Lee J, Yoo CY, Stirm V, Miura T, et al. SIZ1-mediated sumoylation of ICE1 controls CBF3/ DREB1A expression and freezing tolerance in Arabidopsis. Plant Cell. 2007; 19: 1403-1414.

[17] Sukkasem P, Kurniawan A, Kao TC, Chuang HW. A multifaceted rhizobacterium Bacillus licheniformis functions as a fungal antagonist and a promoter of plant growth and abiotic stress tolerance. Environmental and Experimental Botany. 2018; 155: 541-551.

[18] Weisburg WG, Barns SM, Pelletier DA, Lane DJ. 16S ribosomal DNA amplification for phylogenetic study. Journal of Bacteriology. 1991; 173: 697-703.

[19] Altschul SF, Gish W, Miller W, Myers EW, Lipman DJ. Basic local alignment search tool. Journal of Molecular Biology. 1990; 215: 403-410.

[20] Decker EA, Welch B. Role of ferritin as a lipid oxidation catalyst in muscle food. Journal of Agricultural and Food Chemistry. 1990; 38: 674-677.

[21] Kim JS, Kwon YS, Sa YJ, Kim M. Isolation and identification of sea buckthorn (hippophae rhamnoides) phenolics with antioxidant activity and r-glucosidase inhibitory effect. Journal of Agricultural and Food Chemistry. 2011; 59: 138-144.

[22] McCluer RH. Methods in carbohydrate chemistry 1. In: Whistler RL, Wolfrom ML. (eds.) Journal of Chemical Education. 1963. Available from: https://doi.org/10.1021/ed040pA394.

[23] Aebi H, Lester P. Catalase in vitro. Methods in Enzymology. 1984; 105: 121-126.

[24] Nakano Y, Asada K. Hydrogen peroxide is scavenged by ascorbate-specific peroxidase in spinach chloroplasts. Plant and Cell Physiology. 1981; 22: 867-880.

[25] Redman RS, Freeman S, Clifton DR, Morrel J, Brown G, Rodroguez RJ. Biochemical analysis of plant protection afforded by nonpathogenic endophytic mutant of colletotrichummagna. Plant Physiology. 1999; 119: 795-804.

[26] Bruce RJ, West CA. Elicitation of lignin biosynthesis and isoperoxidase activity by pectic fragments in suspension cultures of castor bean. Plant Physiology. 1989; 91: 889-897.

[27] Heath RL, Packer L. Photoperoxidation in isolated chloroplasts. I. Kinetics and stoichiometry of fatty acid peroxidation. Archives of Biochemistry and Biophysics. 1968; 125: 189-198.

[28] Dionisio-Sese ML, Tobita S. Antioxidant responses of rice seedlings to salinity stress. Plant Science. 1998; 135 : 1-9.

[29] Wang W, Scali M, Vignani R, Spadafora A, Sensi E, Mazzuca S, et al. Protein extraction for two-dimensional electrophoresis from olive leaf; a plant tissue containing high levels of interfering compounds. Electrophoresis. 2003; 24: 2369-2375.

[30] Langmead B, Salzberg S. Fast gapped-read alignment with Bowtie 2. Nature Methods. 2012; 9: 357-359.

[31] Li B, Dewey CN. RSEM: Accurate transcript quantification from RNA-Seq data with or without a reference 
genome. BMC Bioinformatics. 2011; 12: 323.

[32] Mittler R, Vanderauwera S, Gollery M, Van Breusegem F. Reactive oxygen gene network of plants. Trends in Plant Science. 2004; 9: 490-498.

[33] Habereder H, Schröder G, Ebel J. Rapid induction of phenylalanine ammonia-lyase and chalcone synthase mRNAs during fungus infection of soybean (Glycine max L.) roots or elicitor treatment of soybean cell cultures at the onset of phytoalexin synthesis. Planta. 1989; 177: 58-65.

[34] Blée E. Impact of phyto-oxylipins in plant defense. Trends in Plant Science. 2002; 7: 315-321.

[35] Paull RE. Chilling injury of crops of tropical and subtropical origin. In: Wang CY. (ed.) Chilling Injury of Horticultural Crops. Boca Raton. FL.: CRC Press; 1990. p.17-36.

[36] McMillan RT, Palmateer A, Vendrame W. Effect of roguing on Erwinia soft rot in commercial production with two Phalaenopsis plants per pot. Proceedings of the Florida State Horticultural Society. 2007; 120: 353-355.

[37] Torres MA, Dangl JL. Functions of the respiratory burst oxidase in biotic interactions, abiotic stress and development. Current Opinion in Plant Biology. 2005; 8: 397-403.

[38] Roppolo D, Boeckmann B, Pfister A, Boutet E, Rubio MC, Dénervaud-Tendon V, et al. Functional and evolutionary analysis of the casparian strip membrane domain protein family. Plant Physiology. 2014; 165: 1709-1722.

[39] Yardim-Akaydin S, Sepici A, Özkan Y, Torun M, Sim, sek B, Sepici V. Oxidation of uric acid in rheumatoid arthritis: Is allantoin a marker of oxidative stress? Free Radical Research. 2004; 38: 623-628.

[40] Kawarazaki T, Kimura S, Iizuka A, Hanamata S, Nibori H, Michikawa M, et al. A low temperature-inducible protein atSRC2 enhances the ROS-producing activity of NADPH oxidase atRbohF. Biochimica et Biophysica Acta. 2013; 1833: 2775-2780

[41] Yannarelli GG, Noriega GO, Batlle A, Tomaro ML. Heme oxygenase up-regulation in ultraviolet-B irradiated soybean plants involves reactive oxygen species. Planta. 2006; 224: 1154-1162.

[42] Sharma I, Ahmad P. Catalase: A versatile antioxidant in plants. In: Ahmad P. (ed.) Oxidative Damage to Plants. Antioxidant Networks and Signaling Academic Press; 2014. p.131-148.

[43] Li S. The Arabidopsis thaliana TCP transcription factors: A broadening horizon beyond development. Plant Signaling and Behavior. 2015; 10: e1044192.

[44] Franken P, Schrell S, Peterson PA, Saedler H, Wienand U. Molecular analysis of protein domain function encoded by the myb-homologous maize genes C1, Zm 1 and Zm 38. Plant Journal. 1994; 6: 21-30.

[45] Tanaka Y, Sasaki N, Ohmiya A. Biosynthesis of plant pigments: Anthocyanins, betalains and carotenoids. Plant Journal. 2008; 54: 733-749.

[46] He XJ, Mu RL, Cao WH, Zhang ZG, Zhang JS, Chen SY. AtNAC2, a transcription factor downstream of ethylene and auxin signaling pathways, is involved in salt stress response and lateral root development. Plant Journal. 2005; 44: 903-916.

[47] Balazadeh S, Kwasniewski M, Caldana C, Mehrnia M, Zanor MI, Xue GP, et al. ORS1, an $\mathrm{H}_{2} \mathrm{O}_{2}$-responsive NAC transcription factor, controls senescence in Arabidopsis thaliana. Molecular Plant. 2011; 4: 346-360.

[48] Maunoury N, Vaucheret H. AGO1 and AGO2 act redundantly in miR408-mediated Plantacyanin regulation. PLoS One. 2011; 6: e28729.

[49] Pradhan M, Pandey P, Baldwin IT, Pandey SP. Argonaute4 modulates resistance to fusarium brachygibbosum infection by regulating jasmonic acid signaling. Plant Physiology. 2020. Available from: https://doi.org/10.1104/ pp.20.00171.

[50] Koo AJK, Chung HS, Kobayashi Y, Howe GA. Identification of a peroxisomal acyl-activating enzyme involved in the biosynthesis of jasmonic acid in Arabidopsis. Journal of Biological Chemistry. 2006; 28: 33511-3320.

[51] Ishiguro S, Kawai-Oda A, Ueda J, Nishida I, Okada K. The defective in anther dehiscience gene encodes a novel phospholipase A1 catalyzing the initial step of jasmonic acid biosynthesis, which synchronizes pollen maturation, anther dehiscence, and flower opening in Arabidopsis. Plant Cell. 2001; 13: 2191-2209.

[52] Dave A, Graham IA. Oxylipin signaling: A distinct role for the jasmonic acid precursor cis-(+)-12-oxophytodienoic acid (cis-OPDA). Front Plant Science. 2012; 3: 42.

[53] Kazan K, Manners J. MYC2: The master in action. Molecular Plant. 2013; 6: 686-703.

[54] Brodersen P, Petersen M, Bjørn Nielsen H, Zhu S, Newman MA, Shokat KM, et al. Arabidopsis MAP kinase 4 regulates salicylic acid-and jasmonic acid/ethylene-dependent responses via EDS1 and PAD4. Plant Journal. 2006; 47: 532-546.

[55] Moffat CS, Ingle RA, Wathugala DL, Saunders NJ, Knight H, Knight NR. ERF5 and ERF6 play redundant roles as positive regulators of JA/Et-mediated defense against botrytis cinerea in arabidopsis. PLoS One. 2012; 7: e35995.

[56] Koops P, Pelser S, Ignatz M, Klose C, Marrocco-Selden K, Kretsch T. EDL3 is an F-box protein involved in the 
regulation of abscisic acid signalling in Arabidopsis thaliana. Journal of Experimental Botany. 2011; 62: 55475560.

[57] Tripathi D, Jiang YL, Kumar D. SABP2, a methyl salicylate esterase is required for the systemic acquired resistance induced by acibenzolar-S-methyl in plants. FEBS Letters. 2010; 584: 3458-3463.

[58] Lasswell J, Rogg LE, Nelson DC, Rongey C, Bartel B. Cloning and characterization of IAR1, a gene required for auxin conjugate sensitivity in Arabidopsis. Plant Cell. 2000; 12: 2395-2408.

[59] Magyar Z, De Veylder L, Atanassova A, Bakó L, Inzé D, Bögre L. The role of the Arabidopsis E2FB transcription factor in regulating auxin-dependent cell division. Plant Cell. 2005; 17: 2527-2541.

[60] Xie Q, Frugis G, Colgan D, Chua NH. Arabidopsis NAC1 transduces auxin signal downstream of TIR1 to promote lateral root development. Genes and Development. 2000; 14: 3024-3036.

[61] Yamaguchi S, Kamiya Y. Gibberellin biosynthesis: Its regulation by endogenous and environmental signals. Plant and Cell Physiology. 2000; 41: 251-257.

[62] Takei K, Sakakibara H, Sugiyama T. Identification of genes encoding adenylate isopentenyltransferase, a cytokinin biosynthesis enzyme, in Arabidopsis thaliana. Journal of Biological Chemistry. 2001; 276: 26405-26410.

[63] Ito Y, Kurata N. Identification and characterization of cytokinin-signalling gene families in rice. Genes. 2006; 382 : $57-65$.

[64] Gómez-Gómez L, Boller T. FLS2: An LRR receptor-like kinase involved in the perception of the bacterial elicitor flagellin in Arabidopsis. Molecular Cell. 2000; 5: 1003-1011.

[65] Guy E, Lautier M, Chabannes M, Roux B, Lauber E, Arlat M, et al. XopAC-triggered immunity against Xanthomonas depends on Arabidopsis receptor-like cytoplasmic kinase genes PBL2 and RIPK. PLoS One. 2013; 8: e73469.

[66] Uknes S, Mauch-Mani B, Moyer M, Potter S, Williams S, Dincher S, et al. Acquired resistance in Arabidopsis. Plant Cell. 1992; 4: 645-656.

[67] Meyers B, Dickerman A, Michelmore R, Sivaramakrishnan S, Sobral B, Young N. Plant disease resistance genes encode members of an ancient and diverse protein family within the nucleotide-binding superfamily. Plant Journal. 1999; 20: 317-332.

[68] Dangl JL, Jones JDG. Plant pathogens and integrated responses to infection. Nature. 2001; 411: 826-833.

[69] Hatsugai N, Yamada K, Goto-Yamada S, Hara-Nishimura I. Vacuolar processing enzyme in plant programmed cell death. Frontiers in Plant Science. 2015; 6: 234.

[70] Yoshiyama KO, Kimura S, Maki H, Britt AB, Umeda M. The role of SOG1, a plant-specific transcriptional regulator, in the DNA damage response. Plant Signaling \& Behavior. 2014; 9: e28889.

[71] Lee KP, Liu K, Kim EY, Medina-Puche L, Dong H, Duan J, et al. Plant natriuretic peptide a and its putative receptor PNP-R2 antagonize salicylic acid-mediated signaling and cell death. Plant Cell. 2020; 32: 2237-2250.

[72] Voigt CA. Callose-mediated resistance to pathogenic intruders in plant defense-related papillae. Frontiers in Plant Science. 2014; 5: 168.

[73] Schmidt S, Dethloff F, Beine-Golovchuk O, Kopka J. The REIL1 and REIL2 proteins of Arabidopsis thaliana are required for leaf growth in the cold. Plant Physiology. 2013; 163: 1623-1639.

[74] Achard P, Gong F, Cheminant S, Alioua M, Hedden P, Genschik P. The cold-inducible CBF1 factor-dependent signaling pathway modulates the accumulation of the growth-repressing della proteins via its effect on gibberellin metabolism. Plant Cell. 2008; 20: 2117-2129.

[75] Koide T, Ohnishi Y, Horinouchi S. Characterization of recombinant $\beta$-amylases from oryza sativa. Bioscience, Biotechnology, and Biochemistry. 2011; 75: 793-796.

[76] Yao X, Xiong W, Ye T, Wu Y. Overexpression of the aspartic protease ASPG1 gene confers drought avoidance in Arabidopsis. Journal of Experimental Botany. 2012; 63: 2579-2593.

[77] Conte SS, Chu HH, Chan-Rodriguez D, Punshon T, Vasques KA, Salt DE, et al. Arabidopsis thaliana Yellow Stripe1-Like4 and Yellow Stripe1-Like6 localize to internal cellular membranes and are involved in metal ion homeostasis. Frontiers in Plant Science. 2013; 4: 283.

[78] Kim MJ, Ruzicka D, Shin R, Schachtman DP. The Arabidopsis AP2/ERF transcription factor RAP2.11 modulates plant response to low-potassium conditions. Molecular Plant. 2012; 5: 1042-1057.

[79] Rauf M, Arif M, Fisahn J, Xue GP, Balazadeh S, Mueller-Roeber B. NAC transcription factor speedy hyponastic growth regulates flooding-induced leaf movement in Arabidopsis. Plant Cell. 2013; 25: 4941-4955.

[80] Krishnaswamy S, Verma S, Rahman MH, Kav NN. Functional characterization of four APETALA2-family genes (RAP2.6, RAP2.6L, DREB19 and DREB26) in Arabidopsis. Plant Molecular Biology. 2011; 75: 107-127.

[81] Li M, Xiong G, Li R, Cui J, Tang D, Zhang B, et al. Rice cellulose synthase-like D4 is essential for normal cell- 
wall biosynthesis and plant growth. Plant Journal. 2009; 60: 1055-1069.

[82] Schuetz M, Benske A, Smith RA, Watanabe Y, Tobimatsu Y, Ralph J, et al. Laccases direct lignification in the discrete secondary cell wall domains of protoxylem. Plant Physiology. 2014; 66: 798-807.

[83] Yang C, Xu Z, Song J, Conner K, Barrena GV, Wilson ZA. Arabidopsis MYB26/MALE STERILE35 regulates secondary thickening in the endothecium and is essential for anther dehiscence. Plant Cell. 2007; 19: 534-548.

[84] Kim SH, Son GH, Bhattacharjee S, Kim HJ, Nam JC, Nguyen PD, et al. The Arabidopsis immune adaptor SRFR1 interacts with TCP transcription factors that redundantly contribute to effector-triggered immunity. Plant Journal. 2014; 78: 978-989.

[85] Cassan-Wang H, Goué N, Saidi MN, Legay S, Sivadon P, Goffner D, et al. Identification of novel transcription factors regulating secondary cell wall formation in Arabidopsis. Frontiers in Plant Science. 2013; 4: 189.

[86] Mitsuda N, Seki M, Shinozaki K, Ohme-Takagi M. The NAC transcription factors NST1 and NST2 of Arabidopsis regulate secondary wall thickenings and are required for anther dehiscence. Plant Cell. 2005; 17: 2993-3006.

[87] Fatima S, Anjum T. Identification of a potential ISR determinant from Pseudomonas aeruginosa PM12 against fusarium wilt in tomato. Frontiers in Plant Science. 2017; 8: 848.

[88] Lugtenberg B, Kamilova F. Plant-growth-promoting rhizobacteria. Annual Review of Microbiology. 2009; 63: 541556.

[89] Kazama D, Itakura M, Kurusu T, Mitsuda N, Ohme-Takagi M, Tada Y. Identification of chimeric repressors that confer salt and osmotic stress tolerance in Arabidopsis. Plants (Basel). 2013; 2: 769-785.

[90] Ahmad P, Rasool S, Gul A, Sheikh SA, Akram NA, Ashraf M, et al. Jasmonates: Multifunctional roles in stress tolerance. Frontiers in Plant Science. 2016; 7: 813.

[91] Zhao ML, Wang JN, Shan W, Fan JG, Kuang JF, Wu KQ, et al. Induction of jasmonate signalling regulators MaMYC2s and their physical interactions with MaICE1 in methyl jasmonate-induced chilling tolerance in banana fruit. Plant, Cell and Environment. 2013; 36: 30-51.

[92] Raza A, Charagh S, Zahid Z, Mubarik MS, Javed R, Siddiqui MH, et al. Jasmonic acid: A key frontier in conferring abiotic stress tolerance in plants. Plant Cell Reports. 2020. Available from: doi:10.1007/s00299-020-02614-z.

[93] Luzzatto T, Yishay M, Lipsky A, Ion A, Belausov E, Yedidia I. Efficient, long-lasting resistance against the soft rot bacterium Pectobacterium carotovorum in calla lily provided by the plant activator methyl jasmonate. Plant Pathology. 2007; 56: 692-701.

[94] Lojkowska E, Holubowska M. The role of polyphenol oxidase and peroxidase in potato tuber resistance to soft rot caused by Erwinia carotovora. Journal of Phytopathology. 1992; 136: 319-328.

[95] Doczi R, Brader G, Pettko-Szandtner A, Rajh I, Djamei A, Pitzschke A, et al. The Arabidopsis mitogen-activated protein kinase kinase MKK3 is upstream of group $\mathrm{C}$ mitogen-activated protein kinases and participates in pathogen signaling. Plant Cell. 2007; 19: 3266-3279.

[96] Carrió-Seguí A, Ruiz-Rivero O, Villamayor-Belinchón L, Puig S, Perea-García A, Peñarrubia L. The altered expression of microRNA408 influences the arabidopsis response to iron deficiency. Frontiers in Plant Science. 2019; 10: 324.

[97] Abdelmajid K, Karim BH, Chedly A. Symbiotic response of common bean (Phaseolus vulgaris L.) to iron deficiency. Acta Physiologiae Plantarum. 2008; 30: 27-34.

[98] Kobayashi T, Itai RN, Senoura T, Oikawa T, Ishimaru Y, Ueda M, et al. Jasmonate signaling is activated in the very early stages of iron deficiency responses in rice roots. Plant Molecular Biology. 2016; 91: 533-547.

[99] La Camera S, Gouzerh G, Dhondt S, Hoffmann L, Fritig B, Legrand M, et al. Metabolic reprogramming in plant innate immunity: the contributions of phenylpropanoid and oxylipin pathways. Immunological Reviews. 2004; 198: 267-284.

[100]Bhuiyan NH, Selvaraj G, Wei Y, King J. Gene expression profiling and silencing reveal that monolignol biosynthesis plays a critical role in penetration defence in wheat against powdery mildew invasion. Journal of Experimental Botany. 2009; 60: 509-521.

[101]Le Gall H, Philippe F, Domon JM, Gillet F, Pelloux J, Rayon C. Cell wall metabolism in response to abiotic stress. Plants. 2015; 4: 112-166.

[102]Vogt T. Phenylpropanoid biosynthesis. Molecular Plant. 2010; 3: 2-20.

[103]Zhang Y, Liang W, Shi J, Xu J, Zhang D. MYB56 encoding a R2R3 MYB transcription factor regulates seed size in Arabidopsis thaliana. Journal of Integrative Plant Biology. 2013; 55: 1166-1178.

[104]Vélez-Bermúdez IC, Salazar-Henao JE, Fornalé S, López-Vidriero I, Franco-Zorrilla JM, Grotewold E, et al. A MYB/ZML complex regulates wound-induced lignin genes in maize. Plant Cell. 2015; 27: 3245-3259.

[105]Sanders PM, Lee PY, Biesgen C, Boone JD, Beals TP, Weiler EW, et al. The arabidopsis delayed dehiscence1 gene 
encodes an enzyme in the jasmonic acid synthesis pathway. Plant Cell. 2000; 12: 1041-1061. 